Yayınlayan: Ankara Üniversitesi KASAUM

Adres: Kadın Sorunları Araştırma ve Uygulama Merkezi, Cebeci 06590 Ankara

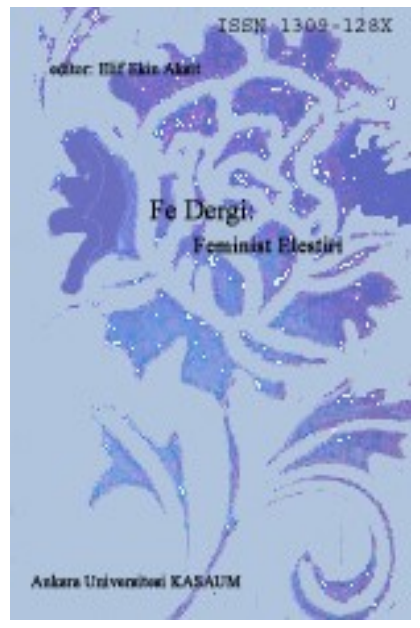

Fe Dergi: Feminist Eleştiri 12, Sayı 2

Erişim bilgileri, makale sunumu ve ayrıntılar için:

http://cins.ankara.edu.tr/

Contribution of Geographical Research Methods to the Study of Gender Relations

Gökben Demirbaș

Çevrimiçi yayına başlama tarihi: 20 Aralık 2020

Yazı Gönderim Tarihi: 04.11.2019

Yazı Kabul Tarihi: 17.09.2020

Bu makaleyi alıntılamak için: Gökben Demirbaş, "Contribution of Geographical Research Methods to the Study of Gender Relations," Fe Dergi 12, no. 2, 88-102.

URL: http://cins.ankara.edu.tr/24_7.pdf

$\mathrm{Bu}$ eser akademik faaliyetlerde ve referans verilerek kullanılabilir. Hiçbir şekilde izin alınmaksızın çoğaltılamaz. 


\title{
Contribution of Geographical Research Methods to the Study of Gender Relations Gökben Demirbaş**
}

\begin{abstract}
Geographical research methods have been increasingly used in social sciences due to the interest in how social behaviour and space are mutually constructed. However, there is still a limited number of studies dealing with the application of such methods, the variety of produced data, and field experiences. In this paper, I reflect on fieldwork experiences of my doctoral research, which investigated how gender and class dynamics shape women's experiences of leisure at the neighbourhood level. During the eight-month fieldwork between 2014-2015, I used the methods of the walk and talk interviews, focus groups with mapping exercises and participant observation in leisure spaces of two differently-classed neighbourhoods in Bursa, Turkey. These methods provide participants with new possibilities of expression, beyond verbal communication capacities, allowing researchers to think about questions that may not necessarily arise in traditional sit-in interviews. Therefore, this article concludes by suggesting that geographical methods can mirror the multilayered and complex nature of gendered social relations
\end{abstract}

Anahtar Kelimeler: gender, method, neighbourhood, leisure

\section{Cŏgrafi Araştırma Yöntemlerinin Toplumsal Cinsiyet İlişkilerinin İncelenmesine Katkısı}

Sosyal davranış ve mekânın birbirini nasıl karşılıklı olarak ürettiği konusuna ilginin artmasına paralel olarak sosyal bilimlerde coğrafi araştırma yöntemlerinin kullanımı da artmaktadır. Bununla birlikte, söz konusu yöntemlerin uygulanışı, ürettikleri verinin niteliği ve sahadaki deneyimlere ilişkin sinırl sayıda kaynak mevcuttur. Bu çalışmada toplumsal cinsiyet ve sınıf dinamiklerinin kadınların mahalle düzeyinde 'serbest zaman' (leisure) deneyimlerini nasıl şekillendirdiğini inceleyen doktora tezimin saha deneyimlerini değerlendiriyorum. 2014-2015 ylllarl içinde toplamda 8 ay süren araştırmamda Türkiye'nin Bursa şehrinin, iki farkl sınıf karakterine sahip mahallesinde, yürü ve konuş görüşmeleri, haritalama tekniklerinin kullanıldı̆̆ odak grup görüşmeleri ve çeşitli leisure mekânlarında katılıml gözlem yöntemlerini kullanarak veri elde ettim. Söz konusu yöntemler, katılımcılar için kendilerini ifade etmede sözel anlatımın sınırlarını aşabilecek yeni imkânlar sağlarken, araştırmacı için de geleneksel yüz yüze görüşmelerde akla gelmeyecek yeni soruların sorulmasına olanak sağlayan araçlardır. Bu nedenle, bu makale coğrafi araştırma yöntemlerinin toplumsal cinsiyet iliş̧kilerinin çok katmanlı ve karmaşık yapısını yansıtabileceğini ileri sürmektedir.

Keywords: toplumsal cinsiyet, yöntem, mahalle, leisure

\section{Giriş}

The "cultural turn" in human geography from the 1990s onward sharpened the focus on the mutual and complex constructions of social and spatial aspects of life, which led to an increasing interest in using geographical research methods, e.g. using visual images, mapping exercises etc. How social life operates in urban spaces is particularly important for feminist studies since gendered rules and moral values operate in the physicality of the gendered bodies and their encounter with the broader public; the judgments are made based on how they behave in such spaces. Feminist researches have highlighted that urban spaces are "contested spaces" within which gendered notions of "appropriate" and "respectable" behaviours are negotiated (e.g. Skeggs 1999; Green and Singleton 2006; Watson and Ratna 2011).

\footnotetext{
*Dr., Trakya University, Faculty of Economics and Administrative Sciences, Department of Political Science and Public Administration, : gokbendemirbas@trakya.edu.tr, gokbende@gmail.com, Orc-id: https://orcid.org/0000-0002-0633-4672, Yaz1 Gönderim Tarihi: 04.11.2019, Yazı Kabul Tarihi: 17.09.2020
} 
Neighbourhoods are crucial locations to investigate gender dynamics regarding the issues of community, territory, proximity and familiarity. As the milieu of everyday life, it has an in-between (between home and central public places) and transitive space, where the contact is more repetitive. According to Mayol (1998) the organisation of everyday life is articulated on at least two registers; a) behaviours, and b) the expected symbolic benefits from 'behaving' in the neighbourhood space. 'Visuality/gaze/exposing and being seen' is central in their study as regulating members' relations with the community. Mayol (1998) states that the meanings of behaviours and the symbolic benefits attached to these meanings are all rooted in the cultural traditions of the social groups. Concordantly, women's leisure in the neighbourhood milieu differs from homeleisure and leisure in city public places. The neighbourhoods represent certain classes, lifestyles and appropriated leisure outcomes. They contain a hegemonic classed and gendered relations presented in the forms of hegemonic codes of social conduct. These codes regulate women's access to and practices of leisure in general.

The qualitative inquiry is beneficial in understanding how social life operates in urban spaces, especially in such gender studies. By providing a sustained focus on the context, a qualitative approach foregrounds a detailed understanding of human experience by exploring the complexities on the ground (Rossman and Rallis 2012, 6-8). Furthermore, the increasing use of visual methods and mixed-methods have the potential to collect enriched data. As Willis $(1980,91)$ emphasises in Notes on Method:

It is indeed crucial that a qualitative methodology is confronted with the maximum flow of relevant data. Here resides the power of the evidence to 'surprise', to contradict, specific developing theories. And here is the only possible source for the 'authenticity', the 'qualitative feel', which is one of the method's major justifications.

The geographical research methods carry the potential to bring richer data particularly in terms of nonverbalised forms of information on social life.

I aim to illustrate in this article, by drawing upon my fieldwork research experiences, the ways in which geographical research methods contribute to our knowledge of gender dynamics in women's leisure experiences in neighbourhoods. The first section introduces the research topic by expounding the rationale behind using geographical research methods. It then moves forward to present the methods used in conducting fieldwork. These are walk and talk interviews, focus groups with utilising mapping exercises and participant observation. The discussion of each method and how it contributes to our understanding of gender relations is presented using data sample.

\section{Everyday as a Whole: The Rationale for Using Geographical Research Methods}

Rather than simply adding a gender dimension to existing frames of leisure, early feminist leisure research aimed to de-construct male-centric conceptualisations of leisure highlighting its male bias evident in the separation between paid work and freely chosen leisure activities (Wearing 1998). By the beginning of the 1980s, in the UK, studies such as those of Dixey and Talbot (1982), Deem (1986) and Green et al. (1987) argued that maintaining the concept of leisure is important to claim leisure as a right for women. However, they argued for a context-based analysis that the definition of leisure can only be meaningful if it emerges from the context under investigation. Feminist leisure research emphasised that studying only public spheres of life provided a partial perspective of leisure; rather, the researcher should start from everyday life and treat it is as a whole to understand the relations of private and public spheres of life. Moreover, women should be treated as the subjects of their conditions and should be asked directly for their definitions of leisure and which activities they identify as leisure.

The early feminist sociological work on leisure rejects pre-defined categories of leisure behaviour and taking collected data at face value; therefore, the analyses in these studies defy easy conclusions. The methodological suggestion of starting from the everyday as a whole and critically engaging with the empirical use of the concept of leisure, as well as the invaluable insights into women's understandings of leisure, majorly influenced the design of my research. These points are particularly important for empirical research on women's leisure in a Turkish context where the concept of leisure does not exist as a lexeme, i.e. a word in the language that is more or less directly translated as 'leisure'. Secondly, the design of my research is shaped by an emphasis on constructing gender- and class-based dynamics in a broader context to examine leisure outcomes. 
That said, the analysis of structural aspects, i.e. gender and class, is far from simplistic. The multi-layered analyses and the recognition of diversity, alongside the emphasis on structural aspects in shaping women's leisure, are a central feature of the studies covered above and acknowledged in my research.

Following the aforementioned rationale, the overall strategy in my unstructured interviews and focus group meetings was to grasp information on women's leisure while they provided information on their everyday routines and their relation to their local residential environment. I asked questions about women's free-time activities. However, following the insights provided by feminist researchers (Deem 1986; Dixey and Talbot 1982; Green et al. 1990) and critical anthropological studies on leisure (e.g. Chick 2009), I preferred to ask more general questions on their everyday routines, their hobbies and the things or activities that give them keyif (pleasure) or practices they do or would like to do if they have time and resources as well as decision-making power. During our conversations, I used surrogate concepts, which are already known in the literature and exists in Turkish, such as resting, entertainment, socialising, and cultural activities, and aimed to gather deeper data from there. In this mode of questioning, subjects were encouraged to talk about their individual experiences and perceptions and, albeit implicitly, provide evidence of the interrelationship of preferred and permitted leisure practices and participation, and forms of subjective well-being.

I decided to investigate women's leisure practices not only at home and through sit-down interviews but by using other methods that can reveal meanings, memories and practices in situ about the place of residence and the community within it. I collected data through the walk and talk interviews, focus groups supported with mapping techniques, and lastly participant observation in leisure spaces. Each geographical research method supported my data collection in distinct ways.

\section{Methods and Triangulation of the Data}

The process of conducting the walk and talk interviews, focus group meetings, participant observation went hand in hand, and the data collected were triangulated. Triangulation is understood as a metaphor for integrating knowledge from different sources, thereby gaining a deeper understanding of the phenomena (see Denzin 2012; Bazeley and Kemp 2012; Flick 2017). Although the main data was collected through the walk and talk interviews and focus group meetings, my understanding could not have been the same without participant observation. In both of the main data collection methods, I relied on an open-ended interviewing technique to provide a space for participants to "share ideas, thoughts, and memories in their own words rather than in the words of the researcher" (Reinharz 1992, 19-20). Nonetheless, I drafted interview questions and focus group themes to keep my ideas in order.

\section{Walk and Talk Interviews}

Walk and talk interviews seemed an especially appropriate technique for my study since women's ability to use and/or move through public spaces in Turkey has historically been constrained by the honour code which roots the moral values and practices around femininity and masculinity in the country (Demirbas 2018). The application of honour code is much more visible and stricter in neighbourhood context in regard to the day-today relations and/or existence of the relatives and neighbours close by, which at the end does not leave much space for anonymity.

Walk and talk interview, a type of go-along interview, ${ }^{1}$ is considered to be "effective at capturing data relating to people's experiences of their local residential context" (Carpiano 2008, 263) and of their mobility within it. As a hybrid form of an interview and participant observation, the walk and talk interview is likely to gather richer data by observing participants' spatial practices in situ, meanwhile accessing their experiences and interpretations verbally. Researchers have highlighted several advantages of this method. For instance, walking in the streets, parks etc. of the neighbourhood may allow for "both researcher and participant to be exposed to the multi-sensory stimulation of the surrounding environment" (Evan and Jones 2011, 850). This environment can be used to prompt more discussion or encourage further questioning that may not occur in room-based settings. Moreover, the method can "provide opportunities for the serendipitous and the unanticipated; it can throw up issues of contradiction" (Clark and Emmel 2010, 2). It can capture the sometimes hidden or unnoticed habitual relations with the place and the environment by highlighting environmental perception, spatial practices, biographies, social architecture and social realms in the data gathered (Kusenbach 2003).

There are different options when choosing the route for the walk and talk interview. Firstly, the interviewer can follow the interviewees in their daily routines and go along with them; secondly, she can decide 
where to walk; and lastly, the interviewee can decide on the route (Evan and Jones 2011). In my research, I decided to leave the time and the choice of route in the neighbourhood to the interviewees. This way, I could grasp their mobility decisions and reactions in an environment that was familiar to them. More importantly, I wanted to provide them with a safe environment rather than forcing them to walk in places in which they may feel uncomfortable.

Walk and talk interviews allowed me to arrive at different judgments on the relation of gender and space in each classed-neighbourhood. For instance, in Panayır, ${ }^{2}$ I expected to walk different parts of the neighbourhood with participants living in different sections of it, from different ages, religious sects etc... However, almost every woman I interviewed took me to the walking trail, some directly and some after a little walk in other locations in the neighbourhood. This result made me think about the meaning of that walking trail as a public leisure space for women. The existing literature on women's mobility in urban Turkey has already informed us that the lower-class women often travel with a male family member, with their child(ren) or alone but with a valid excuse (due to honour code and accountability of women's existence outside of the home) which is work or a family responsibility most of the time, e.g. shopping, health etc... (e.g. Ekin Erkan 2006). Yet the interviews for my research are not a "responsibility" but voluntary activities which are arranged in "free time" and do not have any concrete/direct benefits neither for the participant nor for her family. Furthermore, the neighbours, kins and/or family members may develop concern due to seeing 'their' women walking with a stranger who holds a recorder in her hand while chatting. Therefore, I concluded that the construction of the walking trail provided women with a justified space for walking with leisure purpose and set out the physical boundaries of that action.

The experience of walk and talk interview also allowed me to see women's perspectives on the construction of the walking trail differently, which may have not been revealed during sit-in interviews. Some of the examples in my encounters with women during the interviews reflect such perspectives. For instance, before women told me how they felt about the construction of the walking trail, its location and its structure, I thought the trail is built in the wrong location with an inadequate design. I thought women would not use it because it is located along the main road and it is usually busy with traffic. The trail is a straight pathway divided in two by a roundabout, where there are several stores, markets and shops, with males swarming around them, which concern women in terms of honour and safety. However, almost every woman I interviewed took me to this trail for our walk and talk conversation, which not only changed my opinion about the trail but added to my curiosity as to why and how women were using it so frequently. The data collected from some participants clarified these questions. For instance, Asl1 (forty-one-year-old, married, housewife) said that in the beginning women were exposed to the honks of cars passing by and the intense male gaze but women did not care ("tınlamadik") and continued to use this leisure space frequently. Another participant, Deniz (the thirtyseven-year-old, married, shop owner), noted that the location of the trail is beneficial for women compared to a quiet and isolated area that would be less safe for women. In particular, for those women whom out of fear of being harassed would have not been using the trail as often as now. Again, one summer evening we started our interview with Ebru, (twenty-two-year-old, single, accountant), on the trail, which was significantly crowded. We realised that a live TV programme was being broadcasted from the playground which is located a few meters away on the right side of the south edge of the trail. Earlier in the summer, a corporation had announced its plans to build a coal thermal power station in an industrial area close to the neighbourhood. Residents were frustrated and were protesting this project which would cause further pollution of the area. The neighbours who wanted to watch/listen to the live TV programme had gathered along the trail and the green areas conjugant to it. They were chatting in groups. Women seemed to be unconfined in this place more than any other public space within their neighbourhood. At that point, I realised that I had been heavily concentrating on the barriers in front of women's access to and use of public spaces and had some prejudices due to my own experiences. All in all, the walk and talk interviews, in combination with the other methods I used, allowed me to focus less on my own experiences and subjective view of spaces for leisure and focus more on understanding women's subjective views and experiences of the leisure spaces in the neighbourhood.

In the other field of my project, Yasemin Park, ${ }^{3}$ I was again taken to the same route by all women I interviewed. But this time, the reason behind such uniformity was because there was not any other route to walk other than the walking trail in the estate. It was a fully designed space which left no possibility for subjective use or turning places into different spaces of use. Yet, the walk and talk interviews allowed me to see women's views on the estate and its leisure space in situ. My participants talked about their satisfaction with the safety of 
the estate and the abundant green areas to have picnics, chat, and, where children can play in various designated areas for their leisure. The entirely designed nature of the estate left no space for spontaneous activities and varieties in personal route choices. That is how I realised the uniformity and commonality of the experiences of the estate inhabitants in terms of leisure and space use.

\section{Focus Groups with the Utilisation of Mapping Techniques}

I decided to conduct focus group meetings to grasp the 'group interaction' (Kitzinger 1995) to reveal diversity in meanings and experiences. There are several advantages of using maps in focus groups, e.g. participants can better organise their thoughts through the graphical representation of experience, or a map could influence the depth and detail of individual reflections (Wheeldon 2011). In my study, they were used as a tool for capturing group members' varying spatial practices, everyday rhythms, and their sense of place.

Arranging a convenient time was consistently difficult due to employment and/or childcare responsibilities. Most of the employed women from Yasemin Park declined my invitation to participate as they were too busy; sometimes they were abroad for work, or they asked me to visit them in their workplace since they could spare time for me only during work hours. Since it was quite difficult to access this category of women, I had to seize the moments to gather data from them. The employed women did not only combine interviewing with their work but also with their leisure. When I approached a group of women sitting in the tea garden to introduce my research, they stated that the only time they could spare for a focus group meeting was there and then. I did not have my papers, pencils or other resources with me except for my recorder; therefore, mapping techniques were not utilised in this focus group meeting. Nevertheless, I asked the same questions. In a similar vein, sometimes I had to conduct focus group meetings during Reception Day visits. Once again, the women stated that otherwise, it would be very difficult to organise a separate meeting just for the focus group since everybody is very busy. Childcare responsibilities of mothers of small children also affected my fieldwork in particular ways. In both neighbourhoods, some of the participants had to leave in the middle of the meeting to put their child to sleep, to pick them up from school, or to give them food. Despite such cases, I usually had five or six participants on average in each focus group meeting.

Finding a convenient place for focus group meetings was also challenging. For instance, during my pilot study, I searched for a convenient place in Panayır. Seemingly, the most suitable place was the community centre of the neighbourhood. When I walked there, I saw that the neighbourhood football club uses it. Men had gathered on the balcony and were playing cards, laughing and chatting loudly. Remembering the previous studies on segregated usage patterns of places for leisure, I thought the women would feel uncomfortable even if I requested the use of this place from the head of the neighbourhood. Therefore, I had to hold the meeting at my home in the evening after dinner. During the main fieldwork process, my participants' houses were the main locations of focus group meetings besides the Women's Solidarity Association of Panayır, which is the only public indoor space in which women can gather. It was located next to the walking trail and the playground so that children could play. Additionally, the association has its playroom for children, and I had the chance to meet various women that would have been difficult to access otherwise. In Yasemin Park, the most convenient location was the picnic area where women could keep an eye on their children while we conducted the meetings.

I divided the focus groups into two parts. In the first part, the participants were asked to draw actual maps of their neighbourhoods, consisting of places they know and spend time in during an ordinary day. The maps showed a great degree of variety in terms of what mahalle (neighbourhood) means for women. Combining the maps with the collected verbal data, I interpreted these differences as indicators of their mobility and place-use for leisure.

The mapping exercise allowed women to knit and it softened the atmosphere; it let women make jokes and laugh together at their drawings:

Sema: Look, ablam finished it already. What will we do? [Laughter]

Sevim: Well, I will draw a Cin Ali and that's all I can do.

Ada: You are at work all day, maybe you should draw your workplace...

Dila: Hmmm, yours look beautiful

Gül: A good beginning is half the battle; they already did the half. 
This mode of banter was constant during the meetings. In one sense, drawing can be seen as a leisure activity, which refreshed women. Because I gave a blank paper and a pencil to women to draw which for many, who have not been practising it as part of their work or leisure, was a new experience after many years. In a way, drawing was the right way to initiate conversations. The drawing exercise was perceived as similar to a game, something they have not been doing for years, for some since their childhood. Therefore, women had different reactions to the idea of drawing, some resisted and did not want to draw, and some found a way to produce a joke around it.

I was interested in how the mapping technique can deepen conversations during the focus group meetings; what the mapping can help to uncover. There are some aspects impacted upon the composition of maps. Firstly, the different spatial dimensions of the two neighbourhoods manifest themselves in women's maps. As described above Yasemin Park is a high-security estate; its spatial entirety is perceivable by all residents (e.g. Figure 1).

\section{Figure 1: Beril (twenty-year-old, single, university student)'s map of Yasemin Park}

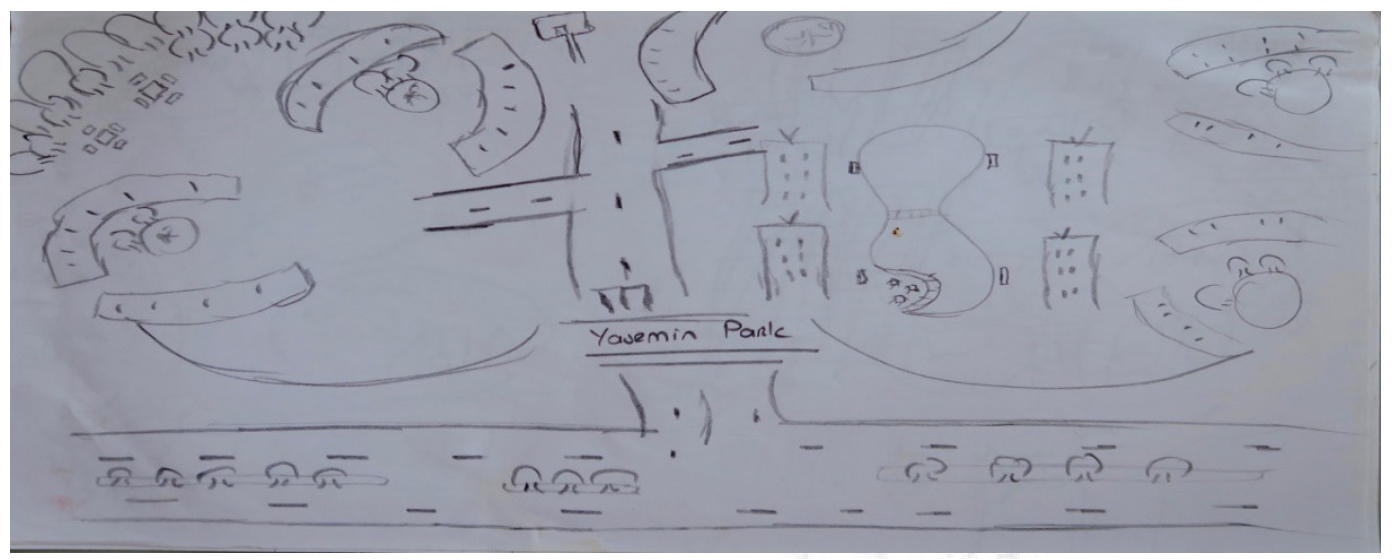

Moreover, the inner areas of the estate are designed for specific leisure purposes which regulate women's use of these spaces (see below Figure 11). All these are reflected in the majority of the maps. In other words, most of the maps represent a bird-eye view of the estate and the number of daily activities women can do in it. Panayır, on the other hand, is a much bigger and more urban sprawl residential area. There is no one map which can represent the entire neighbourhood. Women from Panayır tend to present their subjective use and view of the neighbourhood and they rather collage the places they use and/or want to bring into their maps. In this sense, it is possible to say that the representation of Panayır in the maps are relatively more connected with the subjects who drew them.

In conjunction with this, the historical and class-based oriented differences determine the variances between physical and social facilities of each neighbourhood. These differences eventually are reflected in women's maps. For instance, the maps of Panayır contain more objections than the maps of Yasemin Park. Such unconformities were discussed during the group meetings:

Ada: If I was good at drawing, I would draw the playground over there.

Gül: Draw the geese.

Ada: Since men swarm there, there is no space for us... But I can't draw well. Shall I tell instead?

I realised that for many women, their neighbourhood is the immediate unit surrounding their home, which indicates the limited nature of their mobility or the extent of their everyday. As observed in the first map (Figure 2), Gülin, ${ }^{4}$ (thirty-eight-year-old, married, housewife) spends her days at home and looks out of the window very often; she drew exactly the view from her window. It contains the extent she sees of her street up to the furthest point from her window, and she called it her 'neighbourhood'. She knows her street so well that she even drew the holes on the street filled with rainwater. 
Figure 2: Gülin's map of Panayır

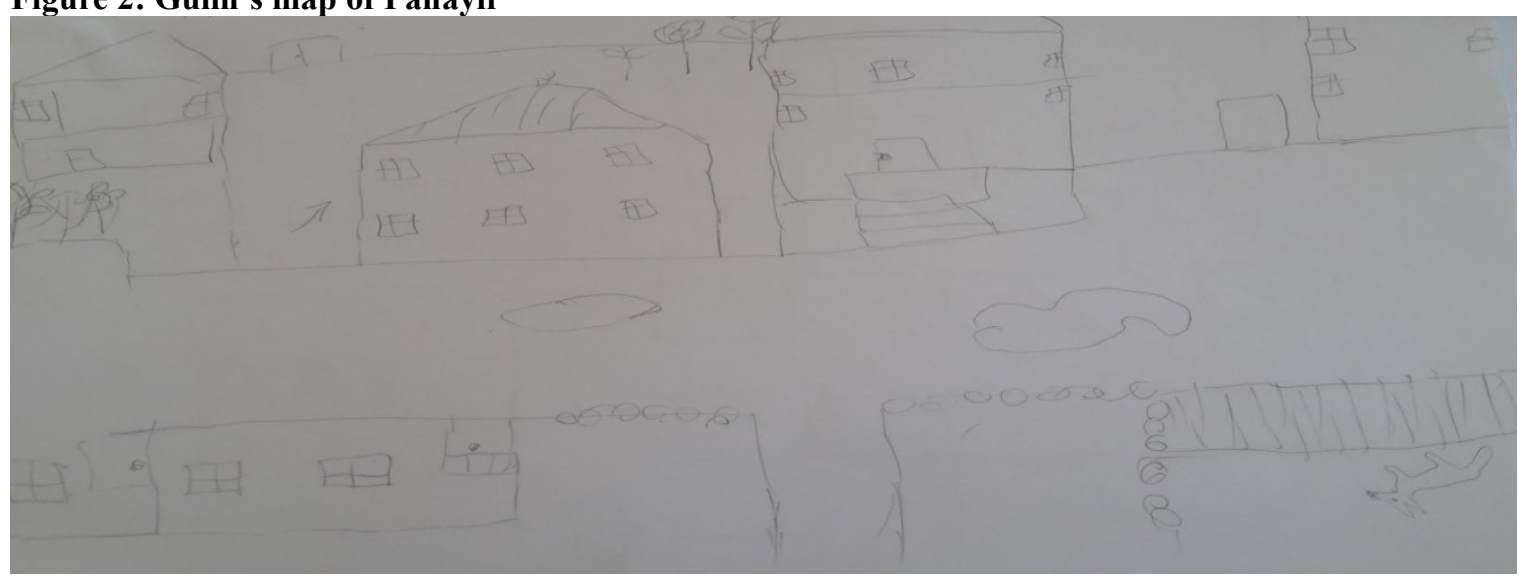

Similarly, Nazlı (thirty-nine-year-old, textile atelier owner, single) describes her map as follows:

I didn't draw my neighbourhood, because, I mean rather the street we live. In other words, where we spend our days, for example, I go out of my flat, I pass the market and arrive at my workplace. Since I spend most of my days in these places, I drew them. So it is not wholly a neighbourhood.

Women who feel more attached to the neighbourhood preferred to draw places that are meaningful and pleasant for them. For instance, Merve (thirty-seven-year-old, married, housewife) who has been living in Panayır for 22 years, drew the square where they have weddings and celebrations (Figure 3). This map has a distinct character since it represents negative and fun aspects of the living environment at the same time. Moreover, the gendered dimension of experiencing the neighbourhood is clear in the drawing.

\section{Figure 3: Merve's map of Panayır}

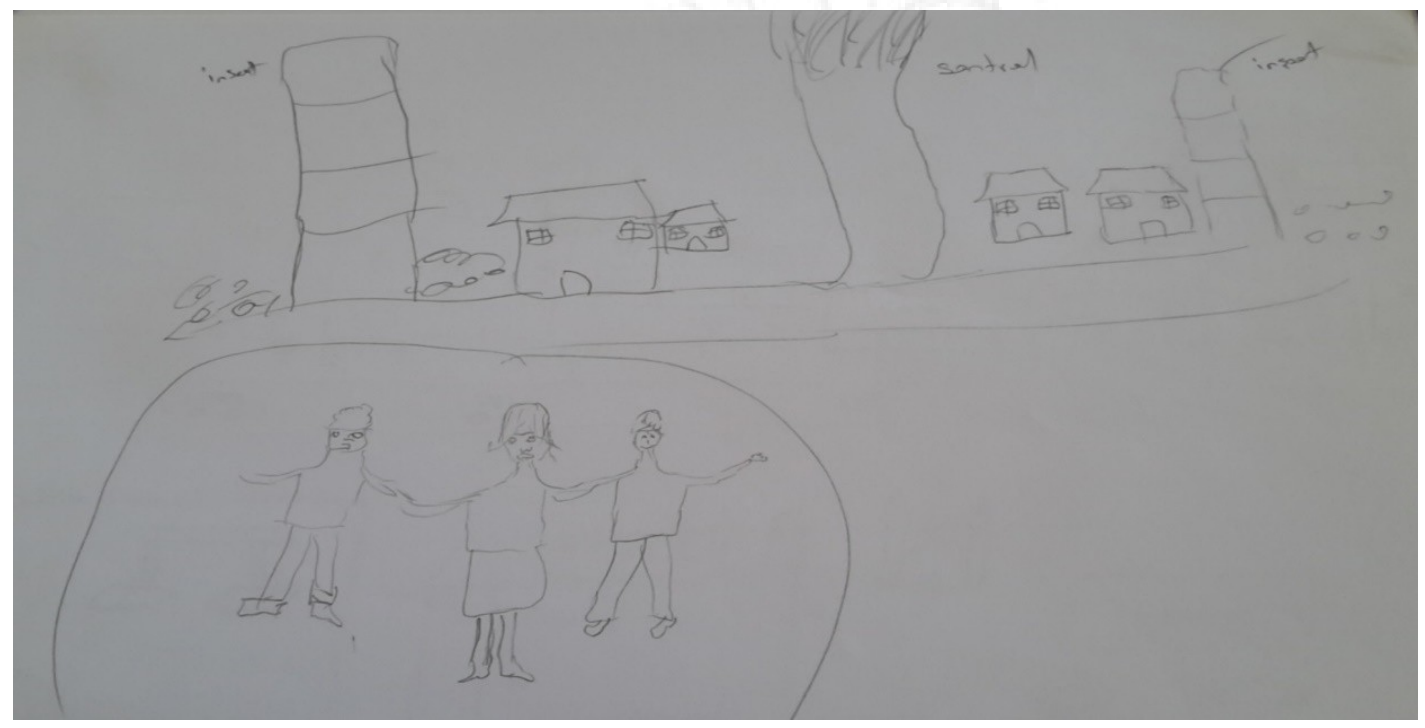

Merve lives in the unit of the neighbourhood which is closer to the Organised Industrial Zone (OIZ). Established in the late 1960s the zone has been expanding towards the neighbourhood and joined it at the end side. There is one power plant in the OIZ and, as mentioned above, another coal thermal power plant is about to be built. Moreover, the unit where Merve lives is improved land and there has been a construction process 

going on in the area. The neighbourhood is not seen as suitable for massive regeneration, but the small construction companies establish small estates with relatively affordable prices. Nevertheless, every possible vacant land is utilised to gain urban rent which results in disturbances for women and children who spend most of their everyday life at home and in other areas of the neighbourhood. In Merve's case, the careless construction process next to her apartment creates noise disturbances and lots of dust. Despite all these negative aspects of everyday life in the neighbourhood, she emphasises the enjoyable events which root her attachment, the square where they organise weddings. This is when her neighbours, relatives and folks meet often during summer evenings and the atmosphere gives her so much pleasure.

Women who feel less attached to the neighbourhood either pointed out their critique on the physical and social environment (Figure 4) or they preferred to draw the neighbourhood in a less personalised way, such as in eye bird view (Figure 5). The two women, whose maps are shown in Figure 4-5 below, are living in the same unit of the neighbourhood. This part of the neighbourhood is constructed without planning permissions and more village-like. People breed chicken, goose and sheep. These animals not only make streets look dirty and produce noise disturbances, but they also make residents feel not part of an urban lifestyle. Moreover, women like Elvin (thirty-year-old, textile atelier owner, single) do not feel part of the neighbourhood because the neighbours sit in front of their houses at summer nights, drink tea, eat sunflower seeds, chat and, laugh. This is especially difficult for neighbours who need to get up early in the morning and go to work. Therefore, women like Elvin feel that they do not share the same notion of living together and do not feel attached to the neighbourhood. This is reflected in her map, which is a non-personalized, bird-eye view of it.

\section{Figure 4: Aslı's map of Panayır}

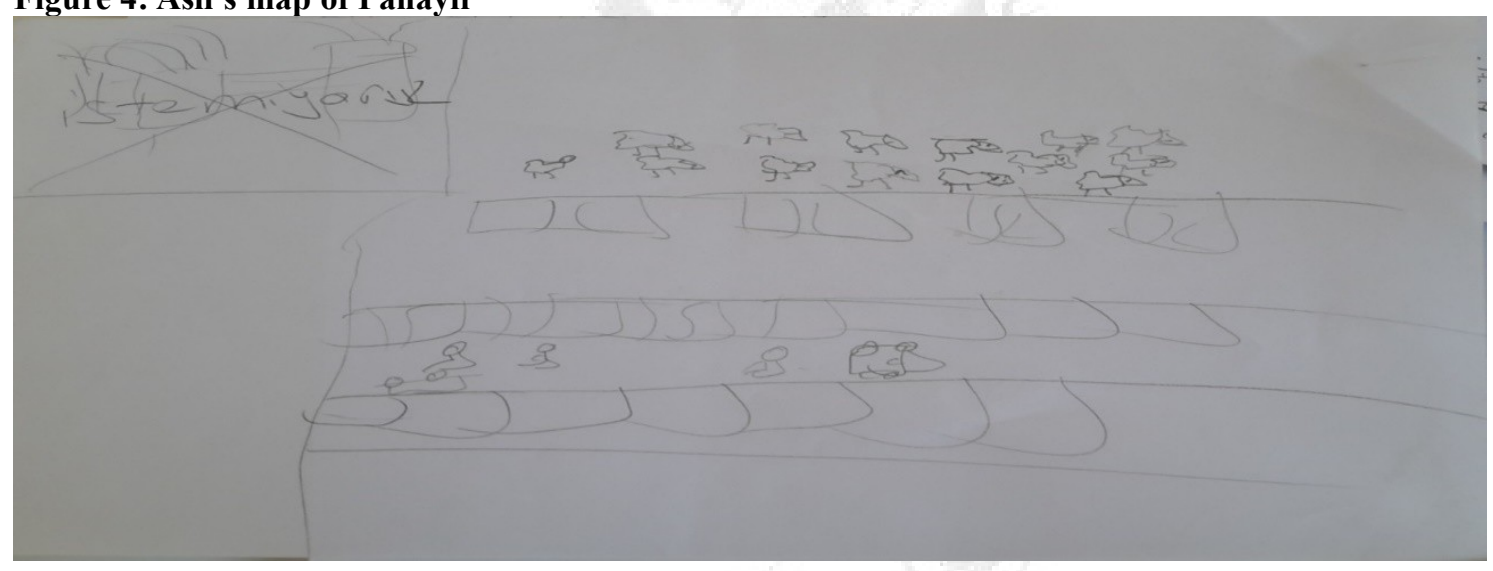

Figure 5: Elvin's map of Panayır

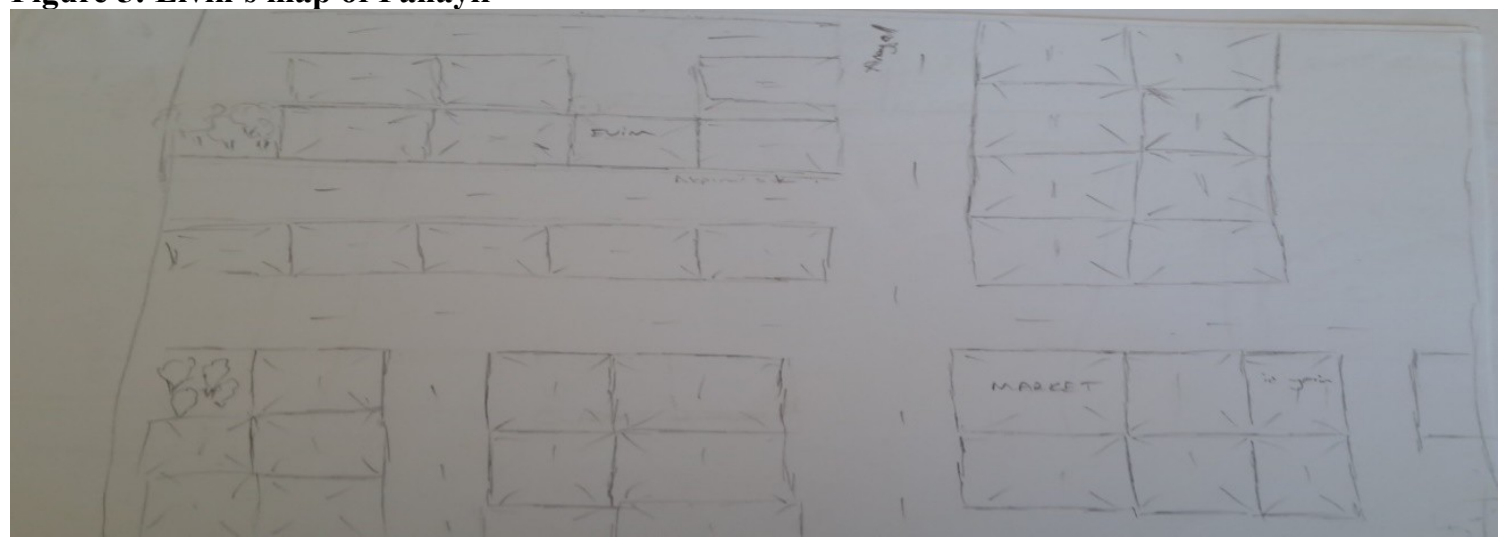

Finally, as exemplified in Ecrin's case (Figure 6), some women drew an imaginary map of the neighbourhood that resembled more a 'Panayır that dreamed of' rather than the actual place. Ecrin (thirty-four- 
year-old, non-employed, married) was born and lived in Antalya in a nice flat before getting married and moving to Bursa. She dislikes aspects of the neighbourhood as she finds many deficiencies in her residential environment. She opted not to display these faults in her map and instead sketched her ideal and imaginary neighbourhood.

Figure 6: Ecrin's map of Panayır

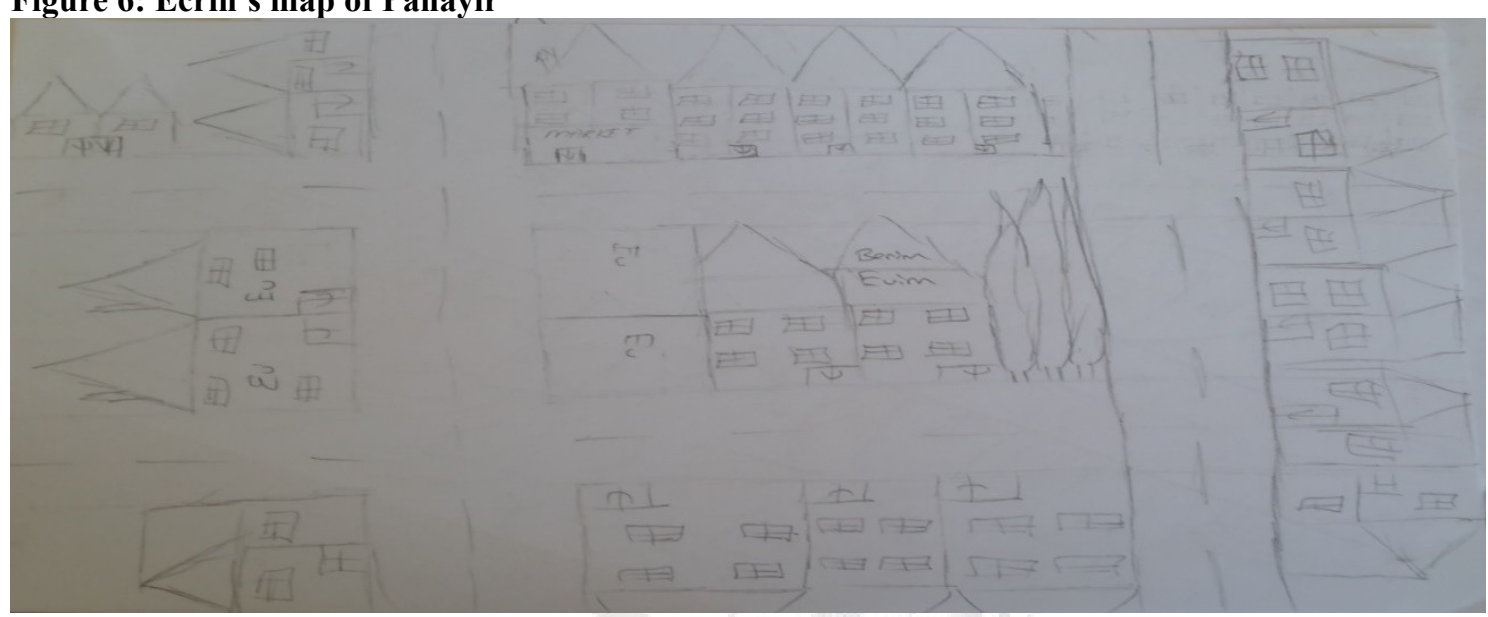

In the second part of each focus group, the participants were asked to draw a mind map of their everyday routines. By using mind maps, I aimed to see how leisure activities embedded into daily routines. A mind map can be understood as "a diagram used to represent words, themes, tasks, or other items linked to and arranged around a central keyword or idea" (Wheeldon and Ahlberg 2012, 24). One of the advantages of mind maps, in comparison to other graphical representation tools, e.g. concept maps, is its more flexible, creative and less formal nature. These features of mind maps allow individuals to represent their personal view and unique style.

I asked my participants to describe their everyday routines by drawing mind maps; their first reaction was to ask me what a mind map is. As Wheeldon and Ahlberg $(2012,33)$ warn the researchers, I had to consider "how explicitly directions are given to participants and how involved the researcher becomes in the process of teaching people to make them...". I first explained what a mind map is to my participants. The difficulty for many women is not being able to visualize a mind map, which they have never done before. Some women asked me whether I can show them an example. I rejected this and it allowed me to see women's creativity in representing activities central to their everyday life, and their most intimate feelings about their everyday routines.

Women represented the repetitive nature of everyday life in different verbal and graphical expression, such as placing their routine around the image of a clock, doing a straight line to show the order of activities or through the expression, e.g. "... and the life goes on". Two examples attract our attention to representing the centre of daily routines. Ecrin presented her mind map as a tree, titled it as "my family" (ailem) (Figure 7). 
Figure 7: Ecrin's mind map

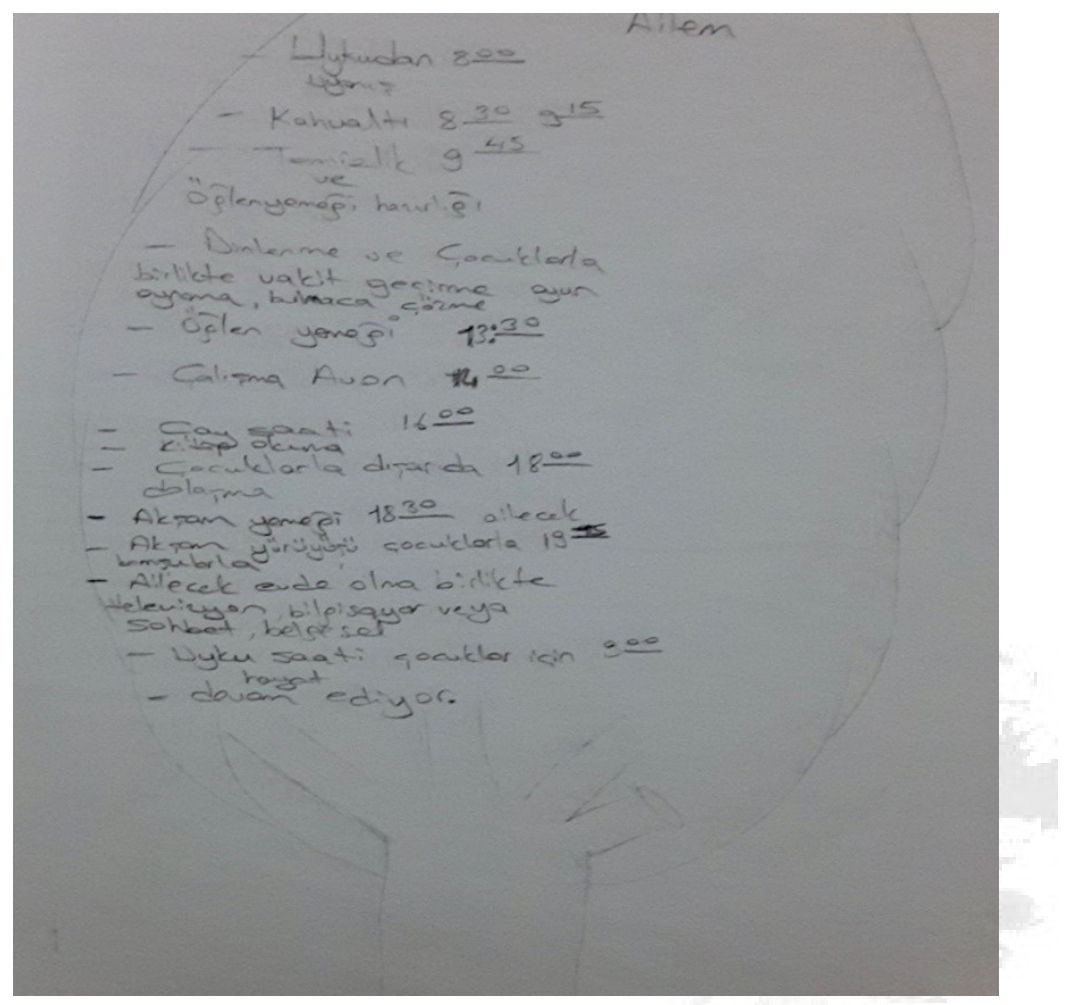

Most of her daily activities are organised around her family and childcare responsibilities. For Elvin, on the other hand, the centre of her everyday is work (Figure 8). Since she does not have care responsibilities for others, other activities organized around work are mostly leisure-related.

\section{Figure 8: Elvin's mind map}

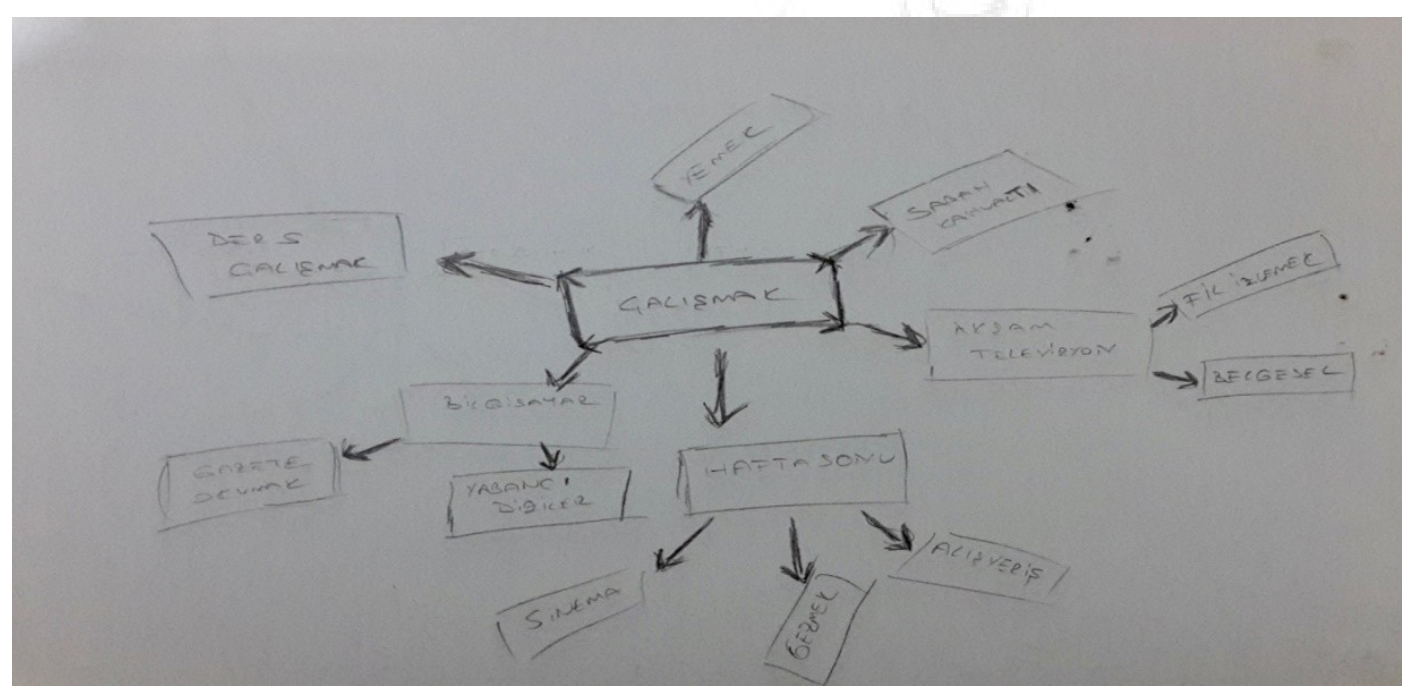


Women's mind maps also represent their feelings about work and leisure. Merve, for example, listed her daily activities; the last number is taken into a circle and expressed joyfully. Here, the time left to herself is defined as "freedom" (Figure 10).

\section{Figure 9: Merve's mind map}

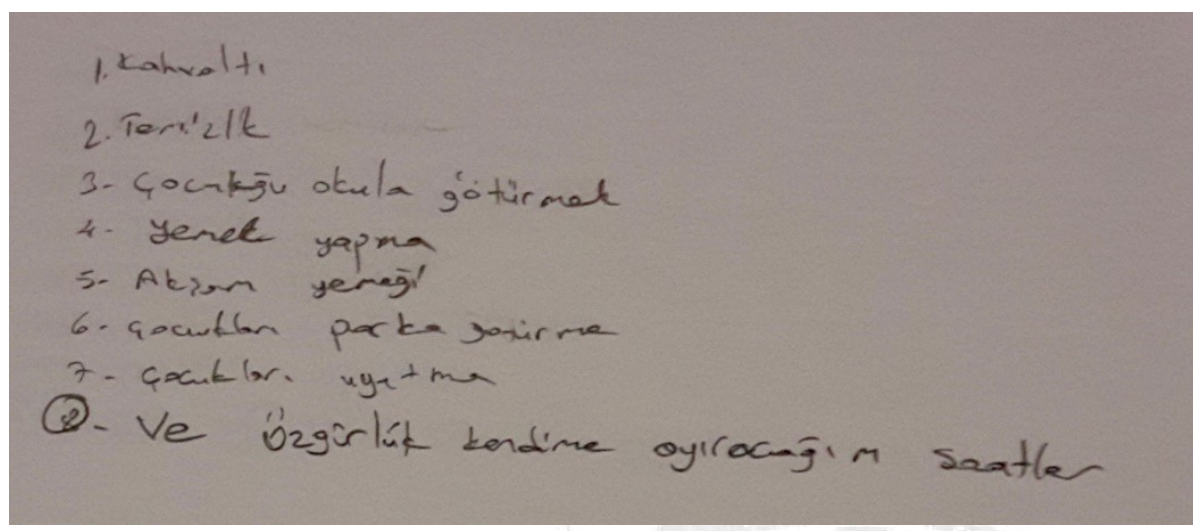

For Sevim (forty-six-year-old, textile worker, married), the absence of time-for-herself decreases her life-satisfaction. After listing her daily activities, and double workload, she describes her feeling of loneliness and dissatisfaction (Figure 10): “A huge loneliness in me, which I couldn't fill; I'm not happy. There is no pleasant side of my life other than I told here".

\section{Figure 10: Sevim's mind map}

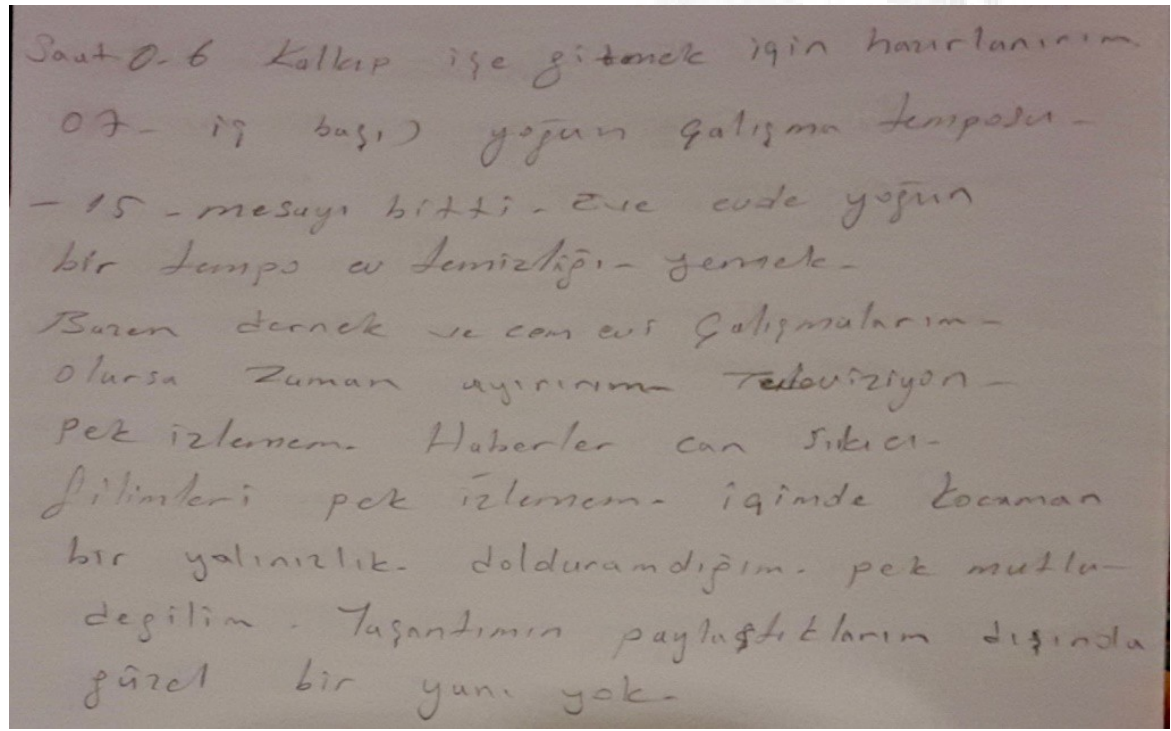

Unlike women from Panayır, most of the women in Yasemin Park preferred to represent their everyday routines in the form of embedding it into the map of the estate. Space-activity combination is very visible in these maps, e.g. Hilal's (thirty-seven-year-old, single, teacher) map (Figure 11). 
Figure 11: Hilal's mind map

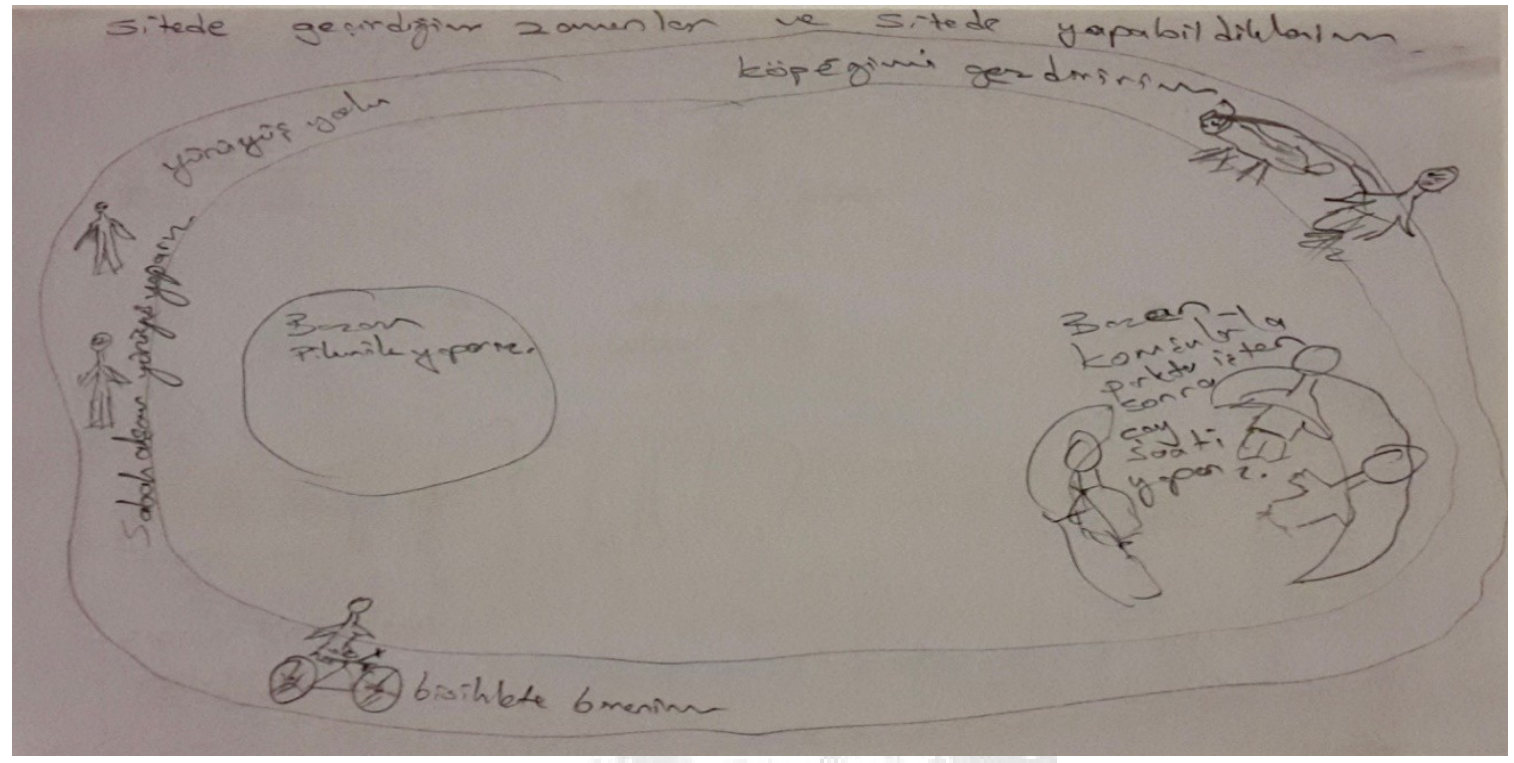

Both actual maps of the neighbourhood and mind maps on everyday life supported my fieldwork in providing a deeper understanding of women's conditions of living, as well as how people's lives are embedded into the physical and material conditions constructing their local environment.

\section{Participant Observation}

The third method I used was the participant observation in places and spaces for leisure, aiming to access individuals' tacit practical knowledge, which cannot be grasped by simply asking questions during interviews (Zahle, 2012). Participant observation provides the researcher with a chance to have spontaneous encounters with a larger number of people and observe their interactions, gestures, and words, as well as the atmosphere in which they occur. While there are two components to the method, namely participation and observation, there are different degrees to which the social researcher may participate in the social setting. For instance, the researcher may do so in the weaker sense of simply hanging around or in the stronger sense of engaging actively in the activities under study (Zahle 2012). In my study participant observation implies hanging around, observing and trying to participate in conversations as little as possible. Researchers such as O'Reilly (2009) and Brewer (2000) also note the ambiguity in the practice of the overt-covert distinction to describe the status of the researcher in the field due to the different levels of openness and the fact that the roles developed in the field, vary with time and location. For instance, at Reception Days, my participation was overt since all of those in attendance knew that I was doing research. During my walks on the walking trail or my conversations on the playground benches or in the tea garden, I did not inform anyone about my role. However, when people started to speak to me, as once occurred in the tea garden in Yasemin Park, I introduced myself as a researcher. My participant observation settings ranged from walking trails to the tea garden, playgrounds, picnic areas and organised home-based gatherings, like Reception Days ${ }^{5}$ and Koran readings ${ }^{6}$.

The participant observation practices allowed me to grasp some of the hidden, less explicitly articulated leisure practices and women's place-making practices. The access and use of playgrounds can be shown as an example at this point. Although the women I interviewed usually brought up the example of playgrounds in terms of their children's leisure needs, my observations foregrounded that most of the women used playgrounds for their leisure, to meet friends, to sit, to chat, and to do some lacework, rather than simply places for their children to play. Yet, the socio-spatial features of the playgrounds determine their gendered use.

Participant observation provided me with insights on how the socio-spatial conditions shape women's presence on and use of the playgrounds. For instance, one night, from eight to eleven pm, I sat on the benches 
of a playground. This place is located in the centre of the surrounding gecekondu apartment buildings and has a more "homely" atmosphere. This location makes the playground almost an inner space and therefore prevents people (mostly men) to use this playground at night for alcohol and/or drug consumption. During my observation, some young women were having a night-time picnic, eating snacks and sunflower seeds, some were walking around. A few women were sitting on sports equipment and doing their lacework while they chatted and kept an eye on their children. Perhaps the most important point to highlight here is the leisureliness in their behaviour. Women usually do not refer to these kinds of space-making exercises in their accounts. The playgrounds located in the centre of the neighbourhood or at the junction of busy roads, on the other hand, are not considered 'safe' even on daylight due to the increased male users in the last years. They bring their children to the playground or they come with other family members or with other men (can be relatives or friends). The increasing use of playgrounds by men has resulted in women's withdrawal from these areas. For instance, one day I went to the playground for observation and I saw that there are five benches, most of which were occupied by men. In one bench one man sits and there is space, but women do not sit there. The presence of male groups on/around benches make women feel uncomfortable as they rather not use the free and available benches. Interpreting this together with women's account provides us with the evidence that the honour code and the spatial segregation of sexes as its consequence are still alive and strong in the neighbourhood which is built through chain migration ${ }^{7}$.

\section{Conclusion}

This article aimed to illustrate how geographical methods can contribute to our analyses of gender relations in urban leisure spaces. The classic definitions of leisure, as a freely chosen, positive experience providing liberty and fulfilment to the individual, have long been criticised by feminist studies underlining the socially constructed, and thereby unequal and exclusionary character of leisure spaces. Women, in particular, face several barriers in access to leisure and in most circumstances merge their leisure with labour activities. Therefore, a context-based analysis of gendered leisure is necessary to grasp how women's leisure is shaped in their everyday routines and spaces. This paper has argued that geographical research methods can have some distinct benefits in revealing the (re)production of gender and space in case of leisure.

Geographical methods supply participants with new possibilities of expression, which overreach verbal communication capacities. By providing extra tools, these methods also have potential in pushing the participants to become creative in their expressions. Mapping exercises during focus groups, for instance, provided participants with new tools to order their thoughts to express their practices, and feelings about their living environments and daily routines. Women's leisure practices are deeply embedded into the socio-spatial conditions of their everyday lives; hence these methods demonstrate the place of leisure in women's' lives, the reasons behind the existence or lack of leisure and the spatial possibilities of leisure within the everyday residential settings.

The methods covered in this article, furthermore, provide chances for researchers to think about questions which may not be conceived in traditional sit-in interviews. The walking interviews and participant observation methods supplied me with the moments of surprise and contradiction, thereby warned me on not putting my expectations from and judgments of the field before my participants' perception on their experiences, possibilities and barriers of leisure. For instance, the reasons behind not getting a variety of places walked together with my participants surprised me and provided me with an insight on how material conditions and gender values come together in the construction of the meaning of leisure spaces. Sometimes the researcher's expectation of outcomes may not show themselves in the field and this non-working nature becomes the tool of investigation. In conclusion, this article highlighted that geographical research methods are powerful elucidators to unfold the gendered character of urban spaces. 
${ }^{1} \mathrm{~A}$ go-along interview is a kind of qualitative interviewing technique where the researchers accompany individual informants on outings in their familiar environments, such as a neighbourhood or larger local area (Carpiano, 2008:264).

${ }^{2}$ Panayır is a typical gecekondu neighbourhood built by rural to urban migrants. During the first half of the 1970s in Bursa, the construction of a number of factories and a new industrial area created a major demand for labour. Migrants started working in these factories and established their gecekondu houses on the vacant land around the industrial area.

${ }^{3}$ Yasemin Park is a high-security estate, originally planned as part of a three-stage gated town project, Yeşilşehir. The population of the estate is approximately 6,000 residents. The story of Yasemin Park is distinct and representative of contemporary Turkey, especially in terms of the shift of capital from manufacturing to the construction sector, the changes in urban land use and the contemporary economic processes (For further information on the neighbourhoods, see Demirbaş 2018).

${ }^{4}$ During focus group meeting, Gülin expressed the ways in which her husband does not allow her to walk around in the neighbourhood and she has to provide details of her whereabouts to her husband.

${ }^{5}$ Reception Day is a leisure activity. Friends/neighbours/colleagues meet on a regular basis, usually once a month, in one of the group members' homes to talk, eat, laugh and chat. Every month members bring a certain amount of money with them, usually a quarter gold coin, to the host. In the end, every member saves the same total amount of money as a result of this activity. Therefore, the activity serves multiple aims: to meet with friends and spend an enjoyable time; to save money; and to establish friendships in the wider community.

${ }^{6}$ Koran readings might be organised for a wide range of reasons: from wishing for the best use of a new property (e.g. moving to a new house) to an important event (e.g. wedding). Women also organise Koran reading groups throughout the year, meeting on a regular basis to read some parts from the Koran and to present stories from the Prophet Mohammad's life. Before and after these activities, they chat, eat and drink together and establish friendships.

${ }^{7}$ The type of migration from rural areas to the cities that has prevailed in Turkey since 1950s is the chain migration (Erder, 1997). Through chain migration, many families from the same village or region have clustered in the same neighbourhood, often in the same gecekondu settlement.

\section{References}

Bazeley, Pat and Lynn Kemp. "Mosaics, Triangles, and DNA: Metaphors for Integrated Analysis in Mixed Methods Research" Journal of Mixed Methods Research 6 (2012): 55-72.

Brewer, John D. Ethnography. (Buckingham: Open University Press, 2000).

Carpiano, Richard. M. "Come take a walk with me: The "Go-Along" interview as a novel method for studying the implications of place for health and well-being” Health \& Place 15 (2008): 263- 272.

Chick, Garry. "Culture as a Variable in the Study of Leisure” Leisure Sciences 31(3) (2009): 305-310

Clark, Andrew and Nick Emmel. "Using walking interviews” Realities 13 (2010):1-6.

De Certeau, Michel, Girard, Luce. and Pierre, Mayol(ed.). The Practice of Everyday Life, Volume 2: Living and Cooking. (Translated by T. J. Tomasik. Minneapolis: University of Minnesota Press, 1988).

Deem, Rosemary. All Work, No Play? (Milton Keynes: Open University Press, 1986).

Demirbaş, Gökben. Women's Leisure in Urban Turkey: A Comparative Neighbourhood Study. (PhD. Glasgow University, 2018).

Denzin, N. K. “Triangulation 2.0.” Journal of Mixed Methods Research. 6, no. 2 (2012): 80-88.

Dixey Rachel and Margaret Talbot. Women, Leisure and Bingo (Trinity and All Saints' College: Indiana University, 1982).

Ekin Erkan, Nihal. Toplumsal Cinsiyet Perspektifinden “Kentsel Eşitsizlik” (PhD. Marmara University, 2006).

Erder, Sema. Kentsel Gerilim. [Urban Tension] (Ankara: Um: Ag Publishing, 1997).

Evan, James and Phil, Jones. "The Walking Interview: Methodology, Mobility and Place" Applied Geography 31 (2011): 849-858.

Flick, Uwe. "Mantras and Myths: The Disenchantment of Mixed-Methods Research and Revisiting Triangulation as a Perspective" Qualitative Inquiry 23, no.1 (2017): 46-57.

Green, Eileen and Hebron, Sandra and Diana Woodward. Leisure and Gender: A Study of Sheffield Women's Leisure Experiences (Sports Council and Economic and Social Research Council, 1987). 
Green, Eileen and Carrie Singleton. "Risky Bodies at Leisure: Young Women Negotiating Space and Place" Sociology, 40, no.5 (2006): 853-871.

Kitzinger, Jenny. “Introducing Focus Groups” British Medical Journal 311 (1995): 299-302.

Kusenbach, Margarethe. "Street Phenomenology: The Go-Along as Ethnographic Research Tool” Ethnography 4, no. 3 (2003): 455-485.

O’Reilly, Karen. Key Concepts in Ethnography (London: Sage Publications, 2009).

Reinharz, S. Feminist Methods in Social Research (Oxford: Oxford University Press, 1992).

Skeggs, Beverley. "Matter out of Place: Visibility and Sexualities in Leisure Spaces" Leisure Studies 18 (1999): 213232.

Watson, Beccy and Aarti Ratna. "Bollywood in the Park: Thinking Intersectionally About Public Leisure Space". Leisure/Loisir. 35, no.1 (2011): 71-86.

Wearing, Betsy. Leisure and Feminist Theory (London: Sage Publication, 1998).

Wheeldon, Johannes. "Is A Picture Worth A Thousand Words? Using Mind Maps to Facilitate Participant Recall in Qualitative Research" The Qualitative Report 16, no.2 (2011): 509-522.

Wheeldon, Johannes and Ahlberg, Mauri, K. Mauri K. Visualizing Social Science Research: Maps, Methods and Meaning (Thousand Oaks: Sage Publication, 2012).

Willis, Paul. (1980). "Notes on Method" Culture, Media and Language: Working Papers in Cultural Studies, $1972-79$ ed. Stuart Hall, Dorothy Hobson, Andrew Lowe and Paul Willis (London: Routledge, 1980), 76-84.

Zahle, Julie. "Practical Knowledge and Participant Observation" Inquiry: An Interdisciplinary Journal of Philosophy 55, no.1 (2012): 50-65. 